\title{
Starch-iodine assay method underestimates $\alpha$-amylase inhibitory potential of antioxidative compounds and extracts
}

\author{
Chimaobi J. Ononamadu ${ }^{1 *}$, Obiajulu C. Ezeigwe ${ }^{2}$, Tajudeen A. OWOlarafe ${ }^{1}$, Godwin O. Ihegboro ${ }^{1}$,

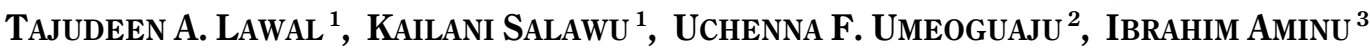 \\ ${ }^{1}$ Department of Biochemistry and Forensic Science, Nigeria Police Academy, Wudil, Kano State, Nigeria \\ ${ }^{2}$ Nnamdi Azikiwe University, Awka, Anambra State, Nigeria \\ ${ }^{3}$ Bayero University, Kano, Kano State, Nigeria
}

\begin{abstract}
Starch-iodine assay method for the determination of $\alpha$-amylase activity is also used in screening extracts for $\alpha$ amylase inhibitors. However, there are indications that this method may not be appropriate for screening some classes of compounds or plant extracts. The present study investigated the limitation(s) of this method in screening plant extracts/compounds for $\alpha$-amylase inhibition. A crude methanol extract (CR) of Dacryodes edulis, its solvent fractions (ethyl acetate (EA), aqueous methanol (AM), and hexane (HX)), quercetin (QC), and benzoic acid (BA) were used for this study. The phytochemical content and antioxidant activity were screened spectrophotometrically. $\alpha$-Amylase inhibition (expressed in percentage and as $\mathrm{IC}_{50}$ ) was determined by starch-iodine method approach I and II (ST-ID I and ST-ID II, respectively) and dinitrosalicylic acid (DNSA) as the control method. The results showed that the extracts/compounds (AM, EA, and QC) with significantly high polyphenolic content, antioxidant activity, and starch-iodine complex decolorization effect yielded contrary results of $\alpha$-amylase inhibition when the results of ST-ID I and II methods were compared to that of the DNSA method. The other test samples (CR, HX, and BA) yielded similar results for all the three methods. The result also showed the decolorization (\%) of starch-iodine complex by the test samples correlated significantly $(r=0.877, P<0.05)$ with DPPH reduction (\%). In conclusion, the present study showed that the starch-iodine method is not appropriate for screening antioxidative extracts/compounds for $\alpha$-amylase inhibitors - they decolorize the assay reagent in a manner similar to DPPH reduction and hence confound the result.
\end{abstract}

Key words: $\alpha$-amylase inhibition, starch-iodine, diabetes mellitus, limitations, decolorization

\section{Introduction}

$\alpha$-Amylase belongs to a class of hydrolase enzymes that cleaves O-glycosidic bonds in starch molecules and related polysaccharides to give diverse products including dextrin and smaller polymers composed of glucose units (Hussain et al., 2013). The enzyme can be derived from several sources, including plants, animals, and microorganisms (Hussain et al., 2013). It plays a dominant role in starch metabolism in animal growth, during grain development, and in germination. It is synthesized under the influence of growth hormones and exists in multiple forms (Cheng et al., 2014; Csiszar et al., 2010). Mammalian $\alpha$-amylase is a prominent enzyme in pan- creatic juice, which breaks down large and insoluble starch molecules into absorbable molecules, ultimately maltose (Gupta et al., 2003). In recent times, inhibitors of $\alpha$-amylase have gained huge research interest in the management of diabetes mellitus. They act by delaying the breakdown of carbohydrates in the small intestine and decreasing the postprandial blood glucose excursion levels in patients with diabetes. Thus, it is common to find many research studies that have screened plant-, animal-, and microbial-derived compounds and extracts for candidate amylase and glucosidase inhibitors $(\mathrm{Abu}$ Soud et al., 2004; Sudha et al., 2011; Unnikrishnan et al., 2015; Pujiyanto et al., 2018).

\footnotetext{
* Corresponding author: Department of Biochemistry and Forensic Science, Nigeria Police Academy, Wudil, PMB 3474, Kano, Kano State 3474, Nigeria; e-mail: ononamaducj0016@gmail.com
} 
Several methods are currently available for testing $\alpha$-amylase activity: starch-iodide (Gupta et al 2003; Xiao et al., 2006), 3,5-dinitrosalicyclic acid (DNSA) (Xiao et al., 2006), Falling Number (FN) (ICC standard booklet, 1999), and Ceralpha method (Megazyme booklet, 2012). These methods are based on the following four principles: 1) decrease in the blue color of starch-iodine complex for the starch-iodine method; this change reflects the endocleavage of starch and can be used routinely to assay $\alpha$-amylase activity; 2 ) increase in the amount of reducing sugars for the DNSA method; it is the most commonly used method for direct measurement of starch hydrolysis because of its reliability and simplicity; 3 ) decrease in the viscosity of starch solution for the FN method, which is accepted as international standard method-ICC Standard No. 107; and 4) degradation of a color-complexed substrate $\rho$-nitrophenyl maltoheptaoside (BPNPG7) is an example of a chromogenic substrate that is sensitive for $\alpha$-amylase activity determination in the Ceralpha method (ICC standard booklet, 1999; Gupta et al., 2003; Xiao et al., 2006; Megazyme booklet, 2012; Kazeem et al., 2013).

Methods used in monitoring enzyme activities are usually employed in studying the inhibition of the same enzyme. Among the methods for screening plants and plant-derived products/compounds for candidate $\alpha$-amylase inhibitors, two methods have been widely reported: the Nelson Somogyi method based on measuring the amount of reducing sugar released by the yellow complex formed with DNSA and the other method based on measuring the amount of hydrolyzed starch measured by the intensity of the blue-black color of the resulting starch-iodine complex (Nyambe-Silavwe et al., 2015; Kumar et al., 2013; Abdullah and Kasim, 2017; Bahar et al., 2016; Ravi et al., 2017).

The starch-iodine method has received considerable attention because it can be used to screen a large number of potential candidate $\alpha$-amylase inhibitors in a short time frame. This is largely due to its sensitivity and requirement of low-cost reagents and less rigorous protocol (Oliveira et al., 2019). The DNSA method, on the other hand, is very sensitive and stable, but suffers from a relatively high cost of the reagents required and a more rigorous protocol. A recent attempt by our laboratory to adapt the starch-iodine method for rapid screening of column fractions of a crude extract for $\alpha$-amylase inhibition has given rise to questions about its per- formance with some extracts and compounds. It is upon this premise that the present study was conceived. It was aimed to investigate the limitations of the starchiodine method in screening plant extracts for $\alpha$-amylase inhibition using four extracts and two standard compounds: the crude methanol extract (CR) of Dacryodes edulis, its solvent fractions (ethyl acetate (EA), aqueous methanol ( $\mathrm{AM})$, hexane $(\mathrm{HX})$ ), quercetin $(\mathrm{QC})$, and benzoic acid (BA).

\section{Materials and methods}

\section{Chemicals/Reagents}

All reagents used were of analytical grade and were obtained from Loba Chemie (India) and Sigma-Aldrich (China).

\section{Preparation of plant extract and fraction}

Dacryodes edulis leaves were obtained from University of Nigeria Nsukka campus in Enugu State. The plant was identified and authenticated (voucher No: UNNHN0601) by a taxonomist in the Department of Plant Science and Biotechnology, University of Nigeria, Nsukka. The crude extract and particular fractions were prepared as described by Teke et al. (2011) with little modifications. The leaves of $D$. edulis were shade dried and coarsely powdered. A mass of $500 \mathrm{~g}$ of the ground leaves was macerated in 2.51 of methanol for $48 \mathrm{~h}$. The mixture was then filtered and concentrated under reduced pressure in a rotary evaporator at $50^{\circ} \mathrm{C}$. A $20.14 \mathrm{~g}$ of the crude extract was pre-dissolved in $100 \mathrm{ml}$ of methanol and then partitioned into $350 \mathrm{ml}$ of n-hexane in a separatory funnel. The mixture was allowed to stand for $12 \mathrm{~h}$ until clearly separated two phases were formed (upper and lower phases). The upper (n-hexane) phase was collected and concentrated as HX solvent fraction. This was repeated three times. The residual methanol phase was collected, concentrated, re-dissolved in $100 \mathrm{ml}$ of AM (55:45 v/v), and partitioned into $350 \mathrm{ml} \mathrm{EA} \mathrm{three}$ times as described above for $n$-hexane in a separatory funnel. The resulting upper (EA) phase was collected each time, pooled together, and concentrated as the EA solvent fraction, while the lower (AM) phase was collected and concentrated as the AM solvent fraction. The extract and the particular fractions were labeled and preserved for further use in airtight opaque bottles at $-4^{\circ} \mathrm{C}$. 


\section{Determination of total phenolic content}

The total phenolic content was determined spectrophotometrically according to the method described by Saeed et al. (2012) with slight modifications. To $10 \mathrm{ml}$ test tubes containing $0.1 \mathrm{ml}$ of the crude extract, solvent fractions (HX, EA, and AM) each prepared in methanol (in triplicates), $5 \mathrm{ml}$ of distilled water, and $0.5 \mathrm{ml}$ of $(10 \%$ $\mathrm{v} / \mathrm{v})$ Folin-Ciocalteau's phenol reagent prepared in water were added sequentially and shaken. After $5 \mathrm{~min}, 0.5 \mathrm{ml}$ of $2 \% \mathrm{w} / \mathrm{v} \mathrm{Na}_{2} \mathrm{CO}_{3}$ solution was added and mixed thoroughly. The mixture was kept in the dark for $30 \mathrm{~min}$ at room temperature, after which the absorbance was read against a blank (all reagents with methanol substituting the extract) at $765 \mathrm{~nm}$. The standard curve for total phenolics was prepared using gallic standard solution ( 0 to $100 \mathrm{mg} / \mathrm{ml}$ ) following the same procedure as described earlier for the extract. The total phenolics was determined from the calibration curve and expressed as milligrams of gallic equivalents per gram of dried crude extracts or fractions.

\section{Determination of flavonoid content}

Total flavonoid content was determined according to a method reported by Saeed et al. (2012) with slight modifications. To a $10 \mathrm{ml}$ test tube containing $0.3 \mathrm{ml}$ of crude extract, solvent fractions (HX, EA, and AM) each, $3.4 \mathrm{ml}$ of $30 \%$ methanol, $0.15 \mathrm{ml}$ of $\mathrm{NaNO}_{2}(0.5 \mathrm{M})$, and $0.15 \mathrm{ml}$ of aluminum chloride $\left[\mathrm{AlCl}_{3} \cdot 6 \mathrm{H}_{2} \mathrm{O}(0.3 \mathrm{M})\right]$ were added sequentially. After $5 \mathrm{~min}, 1 \mathrm{ml}$ of $\mathrm{NaOH}$ ( $1 \mathrm{M}$ ) was added. The solution was shaken to mix well, and the absorbance of the resulting solutions was measured against the reagent blank (all reagents with methanol substituting the extract) at $506 \mathrm{~nm}$. The standard curve for total flavonoids was prepared using $\mathrm{QC}$ standard solution (0 to $100 \mathrm{mg} / \mathrm{ml}$ ) following the same procedure as described earlier for the extracts. The total flavonoids were determined from the calibration curve and expressed as milligrams of quercetin equivalents per gram of dried crude extracts or fractions.

\section{Antioxidant activity}

(DPPH - 2, 2-diphenyl-1-picrylhydrazyl assay (DSA))

The free radical scavenging activity of the extracts was measured in vitro using 2,2-diphenyl-1-picrylhydrazyl (DPPH) according to a method described by Saeed et al. (2016) with slight modifications. The DPPH stock solution $(0.1 \mathrm{mM})$ was prepared by dissolving $4 \mathrm{mg}$ of DPPH in $100 \mathrm{ml}$ methanol and stored at $20^{\circ} \mathrm{C}$ until required. The working solution was obtained by diluting the DPPH solution with methanol to attain an absorbance of approximately $1.2 \pm 0.09$ at $517 \mathrm{~nm}$ by using a spectrophotometer. A $3 \mathrm{ml}$ aliquot of this solution was mixed with $100 \mu \mathrm{l}$ of various concentrations $(0-200 \mu \mathrm{g} / \mathrm{ml})$ of the crude extract, solvent fractions (HX, EM, and AM) and standard compounds $(\mathrm{QC}$ and $\mathrm{BA})$. The reaction mixture was shaken well and incubated in the dark for 30 min at room temperature. The absorbance was measured at $517 \mathrm{~nm}$. The control was prepared as described above without any sample. The $\%$ scavenging activity was determined by the following equation:

$$
\text { DPPH reduction }(\%)=(A c-A t) / A c \times 100 \text {, }
$$

where $A c$ and $A t$ are the absorbance of the control and tests, respectively. The concentration of the extracts /compounds resulting in 50\% reduction of DPPH was determined graphically.

\section{Antioxidant activity (reducing power assay)}

The reducing power (RP) assay is based on Fe (III) to $\mathrm{Fe}$ (II) transformation in the presence of test samples that can be monitored by measuring the formation of Perl's Prussian blue at $700 \mathrm{~nm}$ as described in Ononamadu et al. (2019). Briefly, various concentrations $(0-200 \mu \mathrm{g} / \mathrm{ml})$ of the extract/fractions $(2 \mathrm{ml})$ were prepared and mixed with $2 \mathrm{ml}$ of phosphate buffer $(0.2 \mathrm{M}, \mathrm{pH} 6.6)$ and $2 \mathrm{ml}$ of potassium ferricyanide $(10 \mathrm{mg} / \mathrm{ml})$. The mixture was incubated at $50^{\circ} \mathrm{C}$ for $20 \mathrm{~min}$ and followed by the addition of $2 \mathrm{ml}$ of trichloroacetic acid (100 mg/l). The mixture was centrifuged at $3000 \mathrm{RPM}$ for $10 \mathrm{~min}$ to collect the supernatant of the solution. A volume of $2 \mathrm{ml}$ from each of the mixture mentioned earlier was mixed with $2 \mathrm{ml}$ of distilled water and $0.8 \mathrm{ml}$ of $0.1 \%(\mathrm{w} / \mathrm{v})$ fresh ferric chloride solution. After $10 \mathrm{~min}$ reaction, the absorbance was measured at $700 \mathrm{~nm}$. A standard curve of ferric sulfate was used to quantify the ferric reduction potential of the extract/fractions. $\mathrm{IC}_{50}$ was determined as the concentration of extract/solvent fraction that gave a reduction equivalence of $50 \mathrm{mM} \mathrm{Fe}{ }^{2+}$.

\section{a-Amylase inhibition assay}

The $\alpha$-amylase inhibitory activity of the selected extracts and compounds was carried out using the DNSA method and two different approaches of the starch-iodide method. The difference in the two approaches of the 
starch-iodide method is the time at which the absorbance of the reaction cocktail was measured following the addition of iodine/potassium iodide solution.

\section{DNSA method}

The DNSA method was carried out according to the method described by Kazeem et al. (2013). In brief, to $250 \mu \mathrm{l}$ of each extract, solvent fraction and compound concentration $(0,50,300,550,800 \mu \mathrm{g} / \mathrm{ml})$ in a test tube in triplicates, the following were added sequentially: $250 \mu \mathrm{l}$ of phosphate buffer $(200 \mathrm{mM}, \mathrm{pH} 6.9$ and containing $6 \mathrm{mM}$ sodium chloride), phosphate-buffered $\alpha$-amylase $(250 \mu \mathrm{l}, 0.05 \mathrm{mg} / \mathrm{ml})$, and starch $(250 \mu \mathrm{l}, 1 \% \mathrm{w} / \mathrm{v})$, and the reaction mixture was incubated for $15 \mathrm{~min}$ at $25^{\circ} \mathrm{C}$. DNSA ( $\left.500 \mu \mathrm{l}\right)$ was added subsequently and then boiled for $5 \mathrm{~min}$. It was then cooled and diluted with $5 \mathrm{ml}$ of $\mathrm{dH}_{2} \mathrm{O}$. The control was prepared in the same manner as the test samples with distilled water replacing the extract. The absorbance of each test tube content was measured at $540 \mathrm{~nm}$ and the percentage of inhibition was calculated as follows:

$$
\% \text { inhibition }=(A c-A t) / A c \times 100,
$$

where $A c$ and $A t$ are the absorbance of the control and tests, respectively.

The concentration of the extracts resulting in 50\% inhibition of the enzyme activity $\left(\mathrm{IC}_{50}\right)$ was determined graphically.

\section{Starch-iodide method (Approach I and II)}

Screening of the selected extracts and compounds for $\alpha$-amylase inhibition was carried out according to the method described in Ferosekhan et al. (2016) with slight modifications. To $250 \mu \mathrm{l}$ of each extract in a test tube $(0$, $50,300,550,800 \mu \mathrm{g} / \mathrm{ml})$ in triplicates, the following were added sequentially: $250 \mu \mathrm{l}$ of phosphate buffer $(200 \mathrm{mM}$, pH 6.9 and containing $6 \mathrm{mM}$ sodium chloride), phosphatebuffered $\alpha$-amylase $(250 \mu \mathrm{l}, 0.05 \mathrm{mg} / \mathrm{ml})$, and starch $(250 \mu \mathrm{l}, 1 \% \mathrm{w} / \mathrm{v})$, and the reaction mixture was incubated for $15 \mathrm{~min}$ at $37^{\circ} \mathrm{C}$. One molar $\mathrm{HCl}(20 \mu \mathrm{l})$ was added to stop the enzymatic reaction, followed by the addition of $100 \mu \mathrm{l}$ of iodine reagent ( $5 \mathrm{mM} \mathrm{I}_{2}$ and $5 \mathrm{mM} \mathrm{KI}$ ). The color change was noted, and the absorbance was read at $625 \mathrm{~nm}$ on a $1 \mathrm{ml}$ cuvette at exactly $1 \mathrm{~min}$ after adding the iodine/iodide solution. For the starch-iodine method approach II, the absorbance was measured $20 \mathrm{~min}$ after adding the iodine reagent. The control reaction representing $100 \%$ enzyme activity contained no test extract or compound. To eliminate the absorbance produced by plant extract, appropriate extract controls without the enzyme were also included. Inhibition of enzyme activity was calculated as follows:

$$
\text { Inhibition }(\%)=(C-S) / C \times 100,
$$

where $S$ is the absorbance of the sample and $C$ is the absorbance of control (no extract, no enzyme). The concentration of the extracts/compounds that resulted in $50 \%$ inhibition of enzyme activity $\left(\mathrm{IC}_{50}\right)$ was determined graphically. Pearson correlation coefficient $(r)$ of the median inhibitory concentrations $\left(\mathrm{IC}_{50}\right)$ of the samples by the two methods was determined $\left(\mathrm{IC}_{50} \mathrm{~s}\right.$ obtained with ST-ID II or ST-ID I method against corresponding $\mathrm{IC}_{50} \mathrm{~s}$ obtained with the DNSA method).

\section{Effect of the extracts on the starch-iodine complex}

The effect of the selected extracts/compounds (AM, ET, HX, CR, QC and BA) on starch iodine complex was carried out as follows: to $100 \mu \mathrm{l}$ of each extract concentration in a $3 \mathrm{ml}$ cuvette tubes $(0.01,0.05,0.1$, $0.2 \mathrm{mg} / \mathrm{ml}$ ) in triplicates, the following were added: starch $(1000 \mu \mathrm{l}, 2.0 \% \mathrm{w} / \mathrm{v}), 1000 \mu \mathrm{l}$ sodium phosphate buffer, $(0.02 \mathrm{M}, \mathrm{pH} 6.9)$ and $400 \mu \mathrm{l}$ of iodine reagent ( $5 \mathrm{mM} \mathrm{I}_{2}$ and $5 \mathrm{mM} \mathrm{KI}$ ). The reaction mixture was shaken and incubated for $60 \mathrm{~min}$ at $25^{\circ} \mathrm{C}$. The absorbance was measured at $0,20,40$, and $60 \mathrm{~min}$. The results were expressed graphically as absorbance against time for each concentration of the extracts/compounds tested. The percentage of decolorization of the starch-iodine complex was computed using the following equation:

Starch-iodine decolorization $(\%)=\left(A_{0}-A_{t}\right) / A_{t} \times 100$, where $A_{0}$ and $A_{t}$ are the absorbance of the reaction mixture at time 0 and time $t$, respectively. The Pearson correlation coefficient between the starch-iodine decolorization percentage and the corresponding DPPH reduction percentage was determined and expressed as a scatter plot.

\section{Statistical analysis}

Statistical analysis was performed using Graphpad prism version 7.0 for $\mathrm{IC}_{50}$ determination, Microsoft excel for graphical presentations, and SPSS (Statistical Package for Social Sciences) version 16 for Pearson correlation and descriptive statistics. All data were expressed as mean \pm SEM. $P<0.05$ was considered to be statistically significant. 


\section{Results}

\section{Phytochemistry and antioxidant activity} of the test extract, fractions, and compounds

The phytochemistry and antioxidant (DPPH scavenging and reducing power) activity of the tested extracts (AM, EA, CR, and HX) and compounds (QC and BA) are presented in Table 1 . The results showed that extracts AM and EA had a significantly $(P<0.05)$ higher content of flavonoids and phenolics (AM: $161.1 \mathrm{mg}$ quercetin eqv, $204 \mathrm{mg}$ gallic acid eqv and EA: $149.2 \mathrm{mg}$ quercetin eqv, $193 \mathrm{mg}$ gallic acid eqv, respectively) relative to $\mathrm{CR}$ and HX (87 mg quercetin eqv, $167 \mathrm{mg}$ gallic acid eqv and $12.5 \mathrm{mg}$ quercetin eqv, $34.0 \mathrm{mg}$ gallic acid eqv, respectively). For the antioxidant activity, a similar trend was observed. The extracts $\mathrm{AM}$ and EA and compound $\mathrm{QC}$ exhibited a significantly $(P<0.05)$ higher DPPH scavenging and reducing power activity (AM: 32.4 and $44.9 \mu \mathrm{g} / \mathrm{ml}$, EA: 41.3 and $40.3 \mu \mathrm{g} / \mathrm{ml}$, and QC 28.5 and $33.9 \mu \mathrm{g} / \mathrm{ml}$, respectively) when compared to extracts CR (69.2 and $96.1 \mu \mathrm{g} / \mathrm{ml})$ and HX (466.8 and $195.9 \mu \mathrm{g} / \mathrm{ml})$ and compound BA (480 and $149.5 \mu \mathrm{g} / \mathrm{ml}$, respectively).

\section{Amylase inhibition assays}

The in vitro $\alpha$-amylase inhibition assay results of the selected extracts and compounds using the starch-iodine methods (approach I and II) and the DNSA method are presented in terms of median inhibitory concentrations $\left(\mathrm{IC}_{50}\right)$ (Fig. 1) and percentage of inhibition (Table 2). The result revealed that $\mathrm{AM}(193.2 \mu \mathrm{g} / \mathrm{ml}$ and $98.3 \%)$, EA $(640.0 \mu \mathrm{g} / \mathrm{ml}$ and $87.2 \%)$, and QC $(210.0 \mu \mathrm{g} / \mathrm{ml}$ and $99.0 \%$, respectively) exhibited significantly higher inhibitory activity relative to $\mathrm{CR}(2802.0 \mu \mathrm{g} / \mathrm{ml}$ and $36.0 \%)$, $\mathrm{HX}(8806.3 \mu \mathrm{g} / \mathrm{ml}$ and 5.5\%), and BA $(8809.0 \mu \mathrm{g} / \mathrm{ml}$ and $6.7 \%$, respectively), but this trend was significantly different in ST-ID I and ST-ID II methods (AM: 4016.0, $7294.6 \mu \mathrm{g} / \mathrm{ml}$ and $12.4,6.8 \%$; EA: 5040.7, $7884.5 \mu \mathrm{g} / \mathrm{ml}$ and 9.9, 6.3\%; QC: 4343.0, 7012.4 $\mu \mathrm{g} / \mathrm{ml}$ and 11.3, 5.0\%; CR: 2174.3, $4634.0 \mu \mathrm{g} / \mathrm{ml}$ and $20.8,6.3 \%$, respectively). $\mathrm{AM}, \mathrm{EA}$, and $\mathrm{QC}$ exhibited a high magnitude of difference in $\mathrm{IC}_{50}$. These differences were most significant relative to the ST-ID II method.

The correlation of the amylase inhibitory activity $\left(\mathrm{IC}_{50}\right)$ of the extracts from the ST-ID I, ST-ID II, DNSA methods is presented in Table 1 . The table showed that the result $\left(\mathrm{IC}_{50}\right)$ obtained with the ST-ID I method correlated statistically and positively $(r=807, P<0.05)$ with the results of the DNSA method. The correlation of ST-ID II result with that of DNSA was not statistically significant $r=0.789, P>0.05)$

\section{Effect of the tested extracts and compounds on the starch-iodine complex}

The effect of the tested extracts and compounds on the starch-iodide (blue-black) complex is presented in Figure 2. The results revealed that the extracts AM and EA and compound QC exhibited a marked dose- dependent decolorization of the blue-black color of the starchiodine complex with time. From Figures $2 \mathrm{~B}, 2 \mathrm{C}$, and $2 \mathrm{D}$, it was observed that the curves for AM, EA, and $\mathrm{QC}$ steeply sloped downward away from the CR, HX, and BA curves to give over 25,50 , and $75 \%$ decolorization within $30 \mathrm{mins}$ for 50,100 , and $200 \mu \mathrm{g} / \mathrm{ml}$ concentrations of $\mathrm{AM}, \mathrm{EA}$, and $\mathrm{QC}$, respectively.

\section{Correlation of the decolorization starch-iodine complex and $\mathrm{DPPH}$}

The comparison of the starch-iodine complex decolorization and DPPH scavenging activity of the selected extracts is presented in Figure 3 as a scatter plot. The percentage decolorization of the starch-iodide complex correlated positively, strongly, and statistically $r=0.877, P>0.05)$ with the DPPH reduction percentage (radical scavenging activity).

\section{Discussion}

The starch-iodine assay method is currently used as a rapid method in screening plants for $\alpha$-amylase inhibitors that could serve as lead compounds in the search for more potent antidiabetic drugs or agents (Kumar et al., 2013; Sudha et al., 2011; Uddin et al., 2014). The present study investigated the limitations of this method in screening plant extracts for $\alpha$-amylase inhibition potential.

The phytochemical screening revealed higher content of polyphenolics (flavonoids and phenolics) in extract/ solvent fractions $\mathrm{AM}$ and EA relative to $\mathrm{HX}$ and $\mathrm{CR}$ (Table 1). This may be largely dependent on the method of extraction and polarity of the extracting solvents. Polarity is an important factor that determines the solubility of phytochemicals in solvents (Martson and Hostettman, 2006). Polar solvents such as methanol, water, and aqueous alcohol and mid-polar solvents such as ethyl acetate and acetone have been shown to preferentially extract 
Table 1. Flavonoid and phenolic contents, and DPPH scavenging activity of the tested extract/fractions and compounds

\begin{tabular}{c|c|c|c|c}
\hline Samples & $\begin{array}{c}\text { Flavonoids } \\
{[\text { mg quercetin eqv/g of sample] }}\end{array}$ & $\begin{array}{c}\text { Phenolics } \\
\text { [mg gallic acid/g of sample] }\end{array}$ & $\begin{array}{c}\text { DSA IC }_{50} \\
{[\mu \mathrm{g} / \mathrm{ml}]}\end{array}$ & $\begin{array}{c}\mathrm{RP} \mathrm{IC}_{50} \\
{[\mu \mathrm{g} / \mathrm{ml}]}\end{array}$ \\
\hline CR & $87.03 \pm 8.0^{\mathrm{b}}$ & $167.0 \pm 10.0^{\mathrm{b}}$ & $69.2 \pm 0.5^{\mathrm{d}}$ & $96.1 \pm 8.3^{\mathrm{c}}$ \\
\hline $\mathrm{HX}$ & $12.54 \pm 8.0^{\mathrm{a}}$ & $34.0 \pm 13.0^{\mathrm{a}}$ & $466.8 \pm 1.2^{\mathrm{e}}$ & $195.9 \pm 9.0^{\mathrm{e}}$ \\
\hline $\mathrm{EA}$ & $149.17 \pm 13.0^{\mathrm{c}}$ & $193.0 \pm 7.0^{\mathrm{c}}$ & $41.3 \pm 0.6^{\mathrm{c}}$ & $40.3 \pm 7.0^{\mathrm{ab}}$ \\
\hline $\mathrm{AM}$ & $161.10 \pm 10.0^{\mathrm{c}}$ & $204.0 \pm 8.0^{\mathrm{c}}$ & $32.4 \pm 0.9^{\mathrm{b}}$ & $44.9 \pm 2.7^{\mathrm{b}}$ \\
\hline $\mathrm{QC}$ & $\mathrm{ND}$ & $\mathrm{ND}$ & $28.5 \pm 1.0^{\mathrm{a}}$ & $33.9 \pm 4.8^{\mathrm{a}}$ \\
\hline $\mathrm{BA}$ & $\mathrm{ND}$ & $\mathrm{ND}$ & $480.5 \pm 11.0^{\mathrm{f}}$ & $149.5 \pm 9.3^{\mathrm{d}}$ \\
\hline
\end{tabular}

$\mathrm{DE}$ - dacryodes edulis, EA - ethyl acetate fraction of $\mathrm{CR}, \mathrm{AM}$ - aqueous methanol solvent fraction of $\mathrm{CR}, \mathrm{HX}$ - hexane solvent fraction of CR, CR - crude methanol extract of DE, QC - quercetin, BA - benzoic acid, DSA - DPPH scavenging assay, $\mathrm{RP}$ - reducing power assay, ND - not determined; superscripts: values bearing different superscripts along a column are significantly different $(P<0.05)$

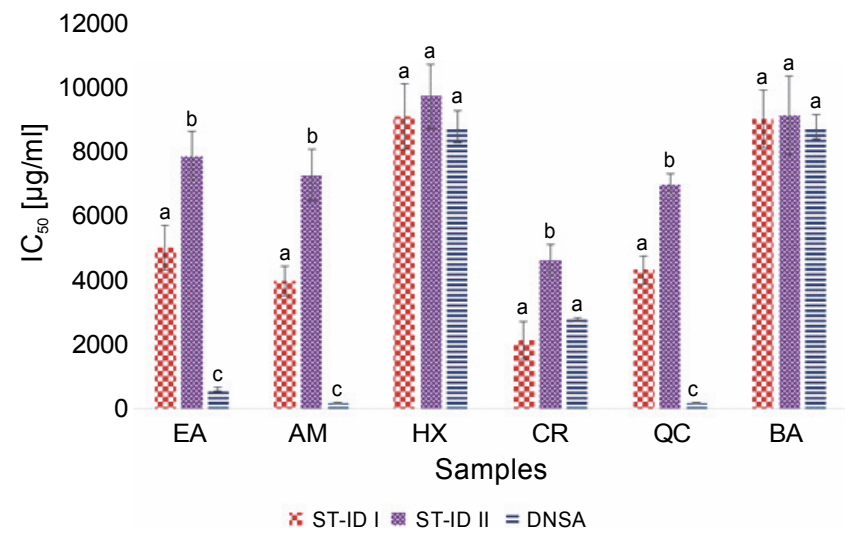

Fig. 1. $\alpha$-Amylase inhibitory activity $\left(\mathrm{IC}_{50}\right)$ of the tested extract/fractions and compounds using the starch-iodine methods and dinitrosalicylic acid (DNSA); ST-ID I - starch-iodine method (approach I), ST-ID II - starch-iodine method (approach II), DNSA - 3,5-dinitrosalicylic acid method, DE - Dacryodes edulis, EA - ethyl acetate solvent fraction of CR, AM - aqueous methanol fraction of $\mathrm{CR}, \mathrm{HX}$ - hexane fraction of $\mathrm{CR}, \mathrm{CR}$ - crude methanol extract of $\mathrm{DE}, \mathrm{QC}$ - quercetin, $\mathrm{BA}$ - benzoic acid; superscripts, values bearing different superscript for each sample are statistically different $(P<0.05)$

polar compounds like polyphenols (Addai et al., 2013; Chikezie et al., 2015; Illoki-Assanga et al., 2015; Chigayo et al., 2016 ). The present study also showed that fractions $\mathrm{AM}$ and $\mathrm{EA}$ and compound $\mathrm{QC}$ exhibited higher antioxidant activity (DPPH scavenging and reducing power) than CR, HX, and BA. This observed higher activity could be attributed to the high polyphenolic content of fractions $\mathrm{AM}$ and EA. On the other hand, $\mathrm{QC}$ is a flavonoid, a class of polyphenols. This finding is corroborated by the reports of Di Meo et al. (2013) and Papuc et al. (2017). They opined that polyphenolic compounds by virtue of their structure (hydroxyl group(s) on a benzene ring(s)) are capable of reducing or scavenging free radicals or oxidants by hydrogen atom or electron transfer.

In principle, $\alpha$-amylase activity using the starch-iodine method is monitored as a function of a decreasing starchiodine complex color from blue-black (unhydrolyzed starch) to a light yellow or light brown (completely or partially hydrolyzed starch) with time (Bahar et al., 2017).

In the present study, the in vitro $\alpha$-amylase inhibitory activity of four extract/fractions and two compounds (AM, EA, CR, HX, QC, and BA) determined using the starch-iodine method and the DNSA method (Gold standard) revealed that fractions AM and EA and compound QC showed widely divergent results when both methods were compared (Fig. 1, Table 1, and Table 2). The result of the starch-iodine methods suggest that the fractions and compound (AM, EA, and QC) inhibited $\alpha$-amylase poorly at the doses assayed; however, the result of the DNSA method suggested otherwise - AM, EA, and QC were strong inhibitors of $\alpha$-amylase. In contrast, the results obtained for extract/fractions $\mathrm{CR}$ and $\mathrm{HX}$ and compound BA were similar for all the methods used. These results suggest that the starch-iodine method may not be suitable for screening some types of compounds because of a possible interference from the phytochemicals of the test extract/fractions or compounds. It is well established that in some assay methods, some compounds have been observed to interfere with the assay reagents and as such confound the results obtained with such methods (van Tonder et al., 2015). These observations are similar to the findings of the present study. The results also revealed that the $\alpha$-amylase inhibition 
Table 2. Percentage of inhibition of $\alpha$-amylase by $800 \mu \mathrm{g} / \mathrm{ml}$ of the tested extract/fractions and compounds for the three assay methods

\begin{tabular}{c|c|c|c}
\hline $\begin{array}{c}\text { Extract/compound } \\
{[\%]}\end{array}$ & ST-ID I & ST-ID II & DNSA \\
\hline EA & $9.9 \pm 0.10^{\mathrm{b}}$ & $6.3 \pm 0.08^{\mathrm{a}}$ & $87.2 \pm 5.30^{\mathrm{c}}$ \\
\hline AM & $12.4 \pm 0.37^{\mathrm{b}}$ & $6.8 \pm 0.51^{\mathrm{a}}$ & $98.3 \pm 2.78^{\mathrm{c}}$ \\
\hline HX & $5.1 \pm 0.54^{\mathrm{a}}$ & $5.7 \pm 0.43^{\mathrm{a}}$ & $5.5 \pm 0.67^{\mathrm{a}}$ \\
\hline CR & $20.8 \pm 3.09^{\mathrm{b}}$ & $10.8 \pm 2.10^{\mathrm{a}}$ & $36.0 \pm 5.30^{\mathrm{c}}$ \\
\hline $\mathrm{QC}$ & $11.3 \pm 0.93^{\mathrm{b}}$ & $5.0 \pm 0.49^{\mathrm{a}}$ & $99.0 \pm 3.89^{\mathrm{c}}$ \\
\hline BA & $4.4 \pm 0.61^{\mathrm{a}}$ & $5.5 \pm 0.49^{\mathrm{a}}$ & $6.7 \pm 0.84^{\mathrm{a}}$ \\
\hline
\end{tabular}

$\mathrm{DE}$ - dacryodes edulis, EA - ethyl acetate fraction of $\mathrm{CR}$, AM - aqueous methanol solvent fraction of $\mathrm{CR}, \mathrm{HX}$ - hexane solvent fraction of $\mathrm{CR}, \mathrm{CR}$ - crude methanol extract of DE, QC - quercetin, BA - benzoic acid, ST-ID I - starchiodide method (approach I), ST-ID II - starch-iodide method (approach II), DNSA - 3,5-dinitrosalicyclic acid method; superscripts: values bearing different superscripts along a column are significantly different $(P<0.05)$

Table 3. Correlation of $\alpha$-amylase inhibitory activity $\left(\mathrm{IC}_{50}\right)$ of the tested extract/fractions and compounds using starch-iodine methods and the DNSA method

\begin{tabular}{l|c|c|c}
\hline & ST-ID method I & ST-ID method II & DNSA method \\
\hline ST-ID method I & - & $r=0.901^{\mathrm{a}}$ & $r=0.807^{\mathrm{a}}$ \\
\hline ST-ID method II & $r=0.901^{\mathrm{a}}$ & - & $r=0.787$ \\
\hline DNSA method & $r=0.807^{\mathrm{a}}$ & $r=0.787$ & - \\
\hline
\end{tabular}

${ }^{\text {a }}$ correlation is significant at the 0.05 level; ST-ID I - starch-iodide method (approach I), ST-ID II - starch-iodide method (approach II), DNSA - 3,5-dinitrosalicyclic acid method

of AM, EA, and QC determined with the ST-ID I method was significantly higher than that determined by the ST-ID II method. This is an indication that the cause of the anomaly observed with the use of the starch-iodine method may be time-dependent, and it may be ameliorated by measuring absorbance immediately after the assay reagent (iodine / potassium iodide solution) is added. The difference in the ST-ID I and ST-ID II assay procedures was the 20-min delay prior to measuring the absorbance in the ST-ID II method. The measurement of absorbance almost immediately after the starch-iodine solution was added limits the contact time between the assay reagent and the test extract/fractions or compounds.

To identify the possible cause of the observed counter results of the amylase inhibitory activities of AM, EA, and QC using the starch-iodine method, the effect of the extract, solvent fractions, and compounds on the starchiodine complex was determined (Fig. 2). The results revealed that the extract/fractions and compounds caused varying degrees of decolorization of the starch-iodine complex in the assay (Fig. 2A-2D). AM, EA, and QC, which showed higher flavonoid and phenolic content and antioxidant (DPPH scavenging and reducing power) activities, exerted the most significant decolorization effect on the starch-iodine complex, while $\mathrm{CR}, \mathrm{HX}$, and BA with lower polyphenolic content and antioxidant activity had a very low decolorization effect relatively. The effect increased tremendously with an increase in the concentration of the extract, solvent fractions, or compounds. It could be observed at higher concentrations that the curves of AM, EA, and QC showed a steeper slope than that of the CR, HX, and BA (Fig. 2C and Fig. 2D) to give almost $100 \%$ (98.9, 98.8, and 98.7\%, respectively) decolorization of the starch-iodine complex at $200 \mu \mathrm{g} / \mathrm{ml}$ after 25 min (Fig. 2D). The result implies that the solvent fractions/compounds (AM, EA, and $\mathrm{QC}$ ) interact with the assay reagent, decolorize the starch-iodine complex, and consequently produce a pseudo amylase activity that masks their inhibitory potential. Du et al. (2014) re- 


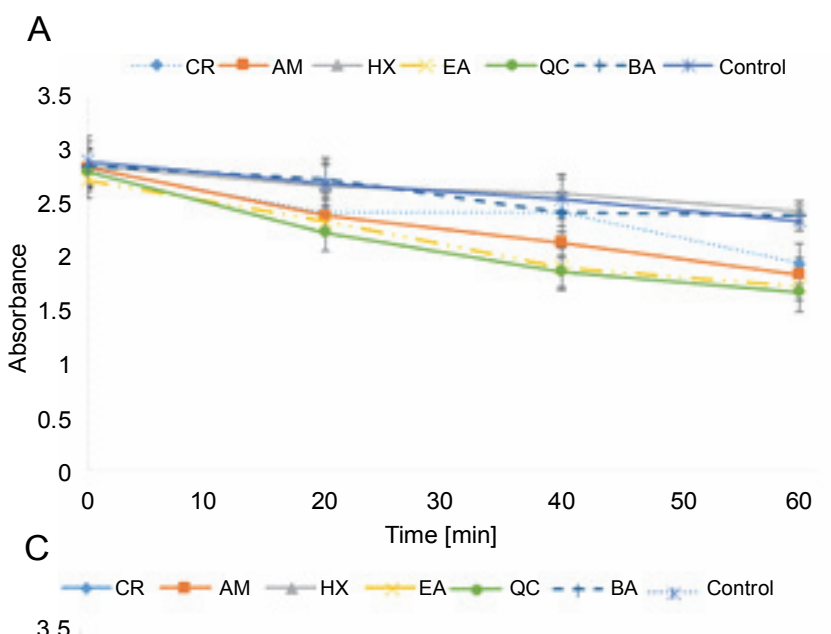

B
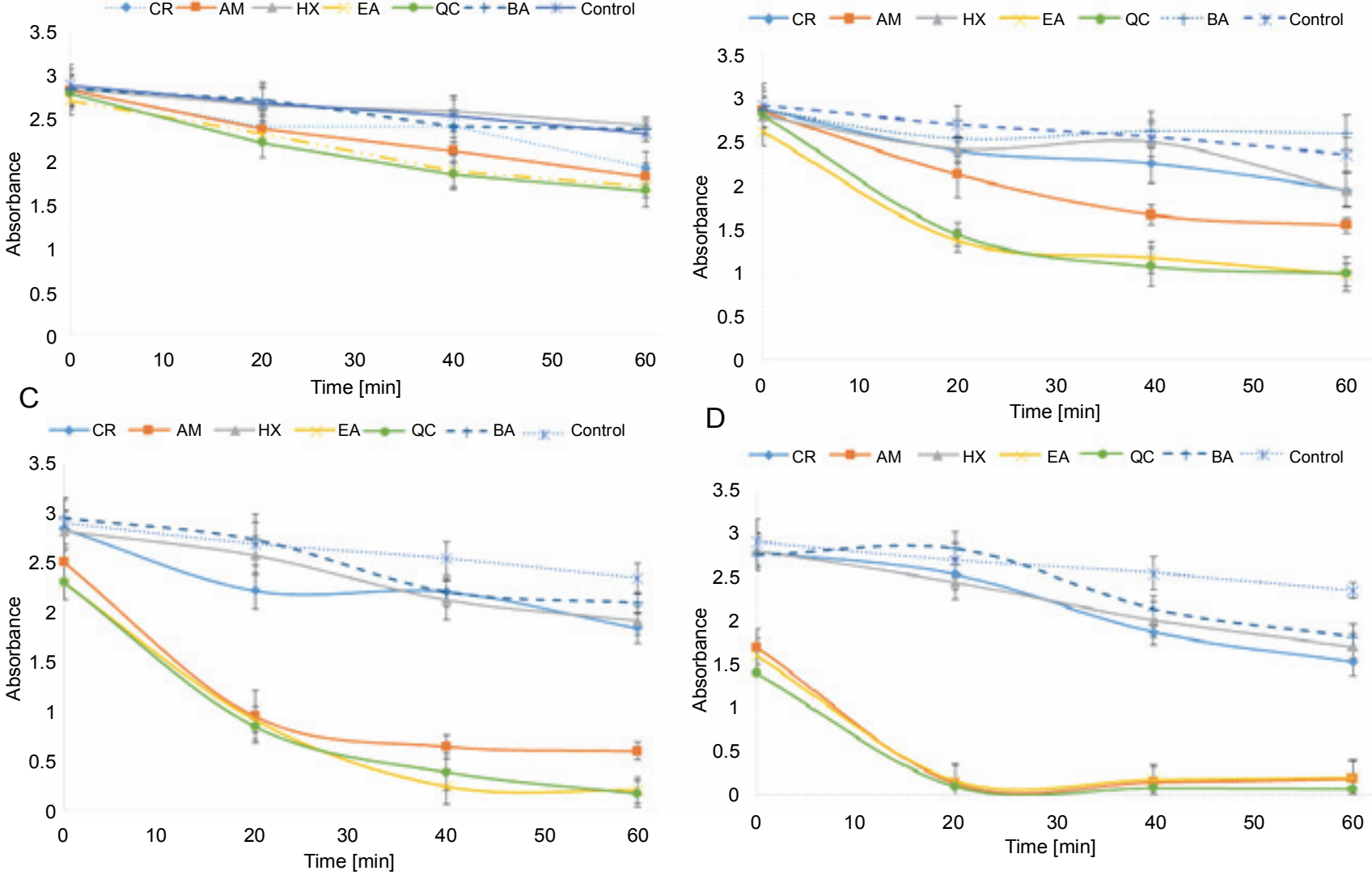

Fig. 2. Effect of the selected extracts on the starch-iodide complex using A) $10 \mu \mathrm{g} / \mathrm{ml}$, B) $50 \mu \mathrm{g} / \mathrm{ml}, \mathrm{C}) 100 \mu \mathrm{g} / \mathrm{ml}$, and D) $200 \mu \mathrm{g} / \mathrm{ml}$ of the tested extract, fractions, and compounds; DE - Dacryodes edulis, EA - ethyl acetate fraction of CR, AM - aqueous methanol fraction of $\mathrm{CR}, \mathrm{HX}$ - hexane fraction of $\mathrm{CR}, \mathrm{CR}$ - crude methanol extract of DE, QC - quercetin, BA - benzoic acid

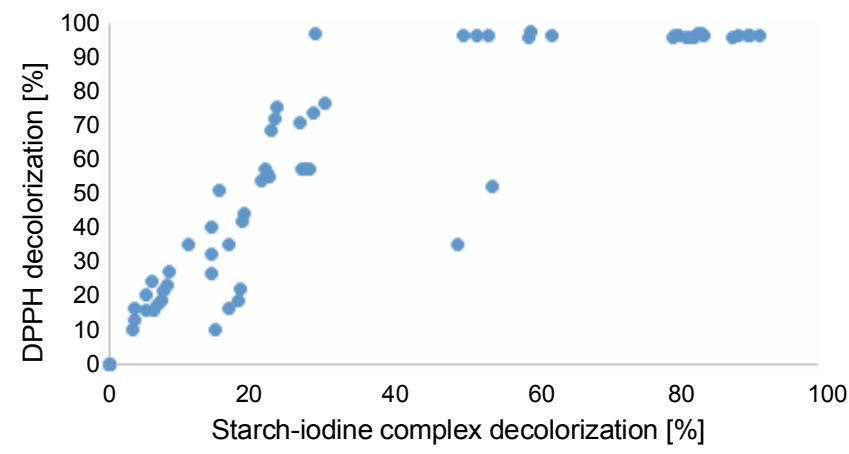

Fig. 3. Correlation of DPPH reduction (\%) and starch-iodine complex decolorization by the tested extract, fractions, and compounds (\%)

ported that the intensity of the blue-black color of the starch-iodine complex could diminish with an increase in temperature or in the presence of water-soluble organic solvents; however, in the present study, the temperature was kept at $37^{\circ} \mathrm{C}$ and there was little or no water-soluble solvents in the system to eliminate the possible contribution of the decolorization effect from the two factors.
Notwithstanding, a critical comparison of the percentage decolorization of the starch-iodine complex observed in the control (without extract) with that of the tests extract/fractions and compounds (Fig. 2A-2D) showed that the decolorization that may have been due to extraneous factors such as temperature $\left(37^{\circ} \mathrm{C}\right)$ and presence of organic solvents in the reaction cocktail was quite minimal and insignificant - the decolorization was largely due to the extract/fractions and compounds.

Structurally, the starch-iodine complex has been reported as a single left-handed helix (of amylose) that accommodates a polyiodide chain (Madhu et al., 2016). In terms of chemistry, the blue-black color is caused by charge-transfer (CT) complexes between the amylose component of starch molecule and the polyiodide chain (Madhu et al., 2016). To further understand the possible chemistry underlining the extracts/compounds decolorizing effect, a correlation test was carried out. A strong positive and statistically $(P<0.05)$ significant correlation $(r=0.877)$ was observed between the starch-iodine 
complex decolorization effect (\%) and the DPPH reducing (decolorization) effect of the extract/fractions and compounds (Fig. 3). Considering the mechanism that underlies the DPPH scavenging activity of compounds or extracts, which has been reported to be either through single electron transfer or hydrogen atom transfer mediated by the hydroxyl groups of their polyphenolics (Pisoschi et al., 2016), the result of the present study suggests that the studied extract/fractions and compounds may have exerted the decolorization effect in a manner similar to that reported for DPPH scavenging activity. The extracts may have destabilized the chargetransfer complex of the amylose-polyiodide structure by acting as a single electron or proton donor and consequently decolorizing the starch-iodine complex. This is further corroborated by the fact that the extracts with high flavonoid and phenolic content (AM and EA) and compound QC, which is a flavonoid, exhibited higher decolorization of the starch-iodine complex. These classes of compounds (flavonoids and phenolics) have been reported to be strong electron and proton donors (Papuc et al., 2017).

Overall, the findings of the present study may be considered similar to a previous report by Pimstone, (1964). Pimestone reported a pseudo amylase activity with the starch-iodine method which he attributed to a significant decolorization of the starch-iodine complex by some serum factors. In the present study, similar interference (which is misconstrued for amylase activity, hence the term pseudo amylase activity) was observed and attributed to highly active and reductive polyphenolic content of the extract and nature of the constituent compounds. Interestingly, other studies have also reported similar limitations in other assay methods such as the MTT assay with the pyruvic acid analogue 3-bromopyruvate (Ganapathy-Kanniappan and Morgan, 2010) and phytochemicals demonstrating intrinsic reductive potential, including antioxidants and polyphenolics (Brugisser et al., 2002; Wang et al., 2006). In conclusion, the findings of the present study suggest that extracts or compounds with high reductive (antioxidant) potential tend to decolorize the starch-iodine complex indicator and consequently confound the result of the starch-iodine assay method. Thus, this method is not appropriate for screening these types of extracts/compounds. However, the method may still be adaptable for quick and first-line screening of extracts/compounds for amylase inhibition in the absence of an alternative method by using very low concentrations of the extract/compound and measuring absorbance immediately after the iodine/iodide solution is added.

\section{Acknowledgment}

The authors appreciate Hajia Hauwa Yakubu, Cadet (ASP) Jonathan Halima H, Cadet (ASP) Unah Paul, Cadet (ASP) Ebube Enendu, and Cadet (ASP) Bagiwa U.L., all from the Department of Biochemistry \& Forensic Science, Nigeria Police Academy, Wudil, for providing the required technical assistance and support for the success of this study.

\section{References}

Abdullah N., Kasim K.F. (2017) In-vitro antidiabetic activity of Clinacanthus nutans extracts. Int. J. Pharmacogn. Phytochem. Res. 9(6): 846-852.

Abu Soud R.S., Hamdan I.I, Afifi F.U. (2004) Alpha amylase inhibitory activity of some plant extracts with hypoglycemic activity. Sci. Pharm. 72: 25-33.

Addai Z.R., Abdullah A., Mutalib S.A. (2013) Effects of extraction solvents on the phenolic content and antioxidant properties of two Papaya cultivars. J. Med. Plants Res. 7(47): 3354-3359.

Bahar E., Akter K.-M., Lee G.-H., Lee H.-Y., Rashid H.-O., Choi M.-K., Bhattarai K.J., Hossain M.M.M., Ara J., Mazumder K., Raihan O., Chae H.-J., Yoon H. (2016) $\beta$-Cell protection and antidiabetic activities of Crassocephalum crepidioides (Asteraceae) Benth. S. Moore extract against alloxan induced oxidative stress via regulation of apoptosis and reactive oxygen species (ROS). BMC Compl. Altern. Med. 17: 179.

Brugisser R., Von Daeniken K., Jundt G., Schaffner W., Tullberg-Reinert H. (2002) Interference of plant extracts, phytoestrogens and antioxidants with the MTT tetrazolium assay. Planta Med. 68: 445-448.

Cheng C.R., Oldach K., Mrva K., Mares D. (2014) Analysis of high pI $\alpha$-Amy-1 gene family members expressed in late maturity $\alpha$-amylase in wheat (Triticum aestivum L.). Mol. Breed. 33: 519-529.

Chigayo K., Mojapelo P.E.L., Mnyakeni-Moleele S., Misihairabgwi J.M. (2016) Phytochemical and antioxidant properties of different solvent extracts of Kirkia wilmsii tubers. Asian Pac. J. Trop. Biomed. 6(12): 1037-1043.

Chikezie P.C., Chiedozie O.I., Mbagwu F.N. (2015a) Bioactive principles from medicinal plants. Res. J. Phytochem. 9(3): 88-115.

Csiszar J., Guóth A., Kolbert Z., Gallé Á., Tari I., Ciulca S., Erdei L. (2010) Starch to protein ratio and $\alpha$-amylase activities in grains of different wheat cultivars. Acta Biol. Szegedien. 54: 19-23.

Di Meo F., Anouar E., Podloucka P., Fabre G., Trouillas P. (2013) Understanding antioxidant properties of natural compounds at the atomic scale. JSSCM 7(1): 58-70.

Du X., An H., Liu Z., Yang H., Wei L. (2014) Probing starch-iodine interaction by atomic force microscopy. Scanning 9999: $1-7$. 
Ferosekhan M., Ramu A., Ravikumar S. (2016) Scientific evaluation of traditionally known insulin plant Costus species for the treatment of diabetes in human. Int. J. Curr. Res. Biosci. Plant Biol. 3(6): 87-91.

Ganapathy-Kanniappan S., Morgan R.H. (2010) The pyruvic acid analogue 3-bromopyruvate interferes with the tetra zolium reagent MTS in the evaluation of cytotoxicity. Assay Drug Dev. Techn. 8(2): 258-262.

Gupta R., Gigras P., Mohapatra H., Goswami V.K., Chauhan B. (2003) Microbial $\alpha$-amylases: a biotechnological perspective. Proc. Biochem. 38: 1599-1616.

Hussain I., Siddique F., Mahmood M.S., Ahmed S.I. (2013) $A$ review of the microbiological aspect of $\alpha$-amylase production. Int. J. Agricult. Biol. 15: 1029-1034.

ICC Standard booklet (1999) Standard methods of the International Association for Cereal Science and Technology. Vienna, ICC. No 303.

Illoki-Assanga S.B., Lewi-Lujan L.M., Lara-Espinoza C.L., GilSalido A.A., Fernandez-Angulo D., Rubio-Pino J.L. David D.H. (2015) Solvent effects on phytochemical constituent profiles and antioxidant activities, using four different extractions formulation for analysis of Bucidabuceras 1. and Phoradendron california. BMC Res. Notes. 8: 396-410.

Kazeem M., Jesuyon V., Ogunbiyi J.V., Ashafa A.O.T. (2013) In vitro studies on the inhibition of $\alpha$-amylase and $\alpha$-glucosidase by leaf extracts of Picralima nitida (Stapf). Tropic. J. Pharm. Res. 12(5): 719-725.

Kumar B.S.A., Khan S., Saran G.S., Nandeesh R., Manjunath N.K. (2013) In vitro antidiabetic activity of Nisamalaki Churna. Sains Malaysian. 42(5): 625-628.

Madhu S., Evans H.A., Doan-Nguyen V.V.T., Labram J.G., Wu G., Chabinyc M.L., Seshadri R., Wudl F. (2016) Infinite polyiodide chains in the pyrroloperylene-iodine complex: insights into the starch-iodine and perylene-iodine complexes. Angew. Chem. Int. Ed. 55: 8032-8035.

Martson A., Hostettman K. (2006) Separation and quantification of flavonoids. [in:] Flavonoids: chemistry, biochemistry and applications. Ed. Anderson Q.M., Markham K.R. New York. Boca Raton: 1-36.

Megazyme booklet (2012) Alpha-amylase assay procedure (Ceralpha method, K-CERA 01/12) for the measurenment of plant and microbial alpha amylases. Wicklow, Ireland: Megazyme International Ireland, Bray Business Park, Bray, Co. 26

Nyambe-Silavwe H., Villa-Rodriguez J., Ifie I. (2015) Inhibition of human $\alpha$-amylase by dietary polyphenols. J. Func. Foods. 19(A): 723-732.

Oliveira H.M., Pinheiro A.Q., Fonseca A.J.M., Cabrita A.R.J., Maia M.R.G. (2019) Flexible and expenditious assay for quantitative monitoring of alpha-amylase and amyloglucosidase activities. MethodsX 6: 246-258.

Ononamadu C.J., Alhassan A.J., Ibrahim A., Imam A.A., Ihegboro G.O., Owolarafe T.A., Sule M.S. (2019) Methanolextract/fractions of Dacryodes edulis leaves ameliorate hyperglycemia and associated oxidative stress in strepto- zotocin-induced diabetic wistar rats. J. Evid.-Based Integr. Med. 24: 1-12.

Papuc C., Goran G.V., Predescu C.N., NicorescuV., Stephan G. (2017) Plant polyphenols as antioxidant and antibacterial agents for shelf life extension of meat and meat products: classification, structures, sources, and action mechanisms. Compr. Rev. Food Sci. Food Safety (6): 1-26.

Pimstone N.R. (1964) A study of the starch-iodine complex: a modified colorimetric micro determination of amylase in biologic fluids. Clin. Chem. 10(10): 891-906.

Pisoschi A.M., Pop A., Cimpeanu C., Predoi G. (2016) Antioxidant capacity determination in plants and plant-derived products: a review. Oxid. Med. Cell. Long. (Article ID 9130976): 1-36.

Pujiyanto S., Resdiani M., Raharja B., Ferniah R.S. (2018) Alpha-amylase inhibitor activity of endophytic bacteria isolated from Annona muricata L. IOP Conference series: J. Phys. 1025: 1-7.

Ravi L., Ragunathan A., Krishnan K. (2017) Antidiabetic and antioxidant potential of gancidinw from Streptomyces paradoxus VITALK03. The Open Bioactive Comp. J. 5: 31-42.

Saeed N., Khan M.R., Shabbir M. (2012) Antioxidant activity, total phenolic and total flavonoid contents of whole plant extracts of Torilis Leptophylla L. Compl. Alter. Med. 12(221): 1-12.

Sudha P., Zinjarde S.S., Bhargava S.Y., Kumar A.R. (2011) Potent $\alpha$-amylase inhibitory activity of Indian Ayurvedic medicinal plants. BMC Compl. Alter. Med. 11(5): 1-10.

Teke G.N., Lunga P.K., Hippolyte K., Wabo H.K., Kuiate J.-R., Vilarem G., Giacinti G., Kikuchi S.H., Oshima Y. (2011) Antimicrobial and antioxidant properties of methanol extract, fractions and compounds from the stem bark of Entada abyssinica Stend ex A.Satabie. BMC Compl. Alter. Med. 11: 57-65.

Uddin N., Hasa, M.R., Hossain M.M., Sarker A., Hasan A.H., Islam A.F., Rana M.S. (2014) In vitro $\alpha$-amylase inhibitory activity and in vivo hypoglycemic effect of methanol extract of Citrus macroptera Montr. fruit. Asian Pacific J. Tropic. Biomed. 4(6): 473-479.

Unnikrishnan P.S., Suthindhiran K., Jayasri M.A. (2015) Alpha-amylase inhibition and antioxidant activity of marine green algae and its possible role in diabetes management. Pharmacogn. Magaz. 11(4): S511-515.

van Tonder A., Joubert A.M., Cromarty A.D. (2015) Limitations of the 3-(4,5-dimethylthiazol-2-yl)-2,5-diphenyl-2Htetrazolium bromide (MTT) assay when compared to three commonly used cell enumeration assays. BMC Res. Notes 8(47): 1-10.

Wang P., Henning S.M., Heber D. (2006) Limitations of MTT and MTS-based assays for measurements of antiproliferative activity of green tea polyphenols. PLoS One. 5(4): $1-10$.

Xiao Z., Storms R., Tsang A. (2006) A quantitative starch-iodine method for measuring alpha-amylase and glucoamylase activities. Anal. Biochem. 351: 146-148. 